National Marine

Fisheries Service

NOAA
Fishery Bulletin

2o established in $1881 \%$
Spencer F. Baird

First U.S. Commissioner of Fisheries and founder of Fishery Bulletin

\begin{abstract}
We investigated youngof-the-year (YOY) growth, age, and hatching distributions of common pandora (Pagellus erythrinus) by analyzing otolith microstructure. This study was carried out in shallow waters $(0-20 \mathrm{~m})$ off the island of Gökçeada, Turkey, from June 2013 through June 2014. A total of 231 YOY common pandora were measured and aged. These fish ranged from 12 to $110 \mathrm{~mm}$ in total length and from 38 through $242 \mathrm{~d}$ in age. The indices for determining variability in daily age estimates (average percentage error and coefficient of variation) were $4.9 \%$ and $3.4 \%$, respectively. Average daily growth rate was calculated from a linear regression of the age-length data set as $0.52 \mathrm{~mm} / \mathrm{d}$. A linear relationship was found between otolith morphometric measurements (otolith length, width, and radius) and total length for YOY common pandora. The hatching times of common pandora were backcalculated to occur from February through October, and 2 main hatching cohorts were evident in spring (March) and summer (August).
\end{abstract}

Manuscript submitted 18 August 2017. Manuscript accepted 13 February 2018. Fish. Bull. 116:183-189 (2018).

Online publication date: 21 February 2018. doi: 10.7755/FB.116.2.7

The views and opinions expressed or implied in this article are those of the author (or authors) and do not necessarily reflect the position of the National Marine Fisheries Service, NOAA.

\title{
Age and growth rates at the early life stages of common pandora (Pagellus erythrinus) based on analysis of otolith microstructure
}

\author{
Hakan Ayyildiz (contact author) \\ Aytac Altin \\ Email address for contact author: ayyildizhakan@gmail.com \\ Department of Fisheries Technology \\ Gökçeada School of Applied Sciences \\ Çanakkale Onsekiz Mart University \\ Yeni Mahalle Dr. Sadık Ahmet Sokak No. 25 \\ Gökçeada, Çanakkale 17760 Turkey
}

The common pandora (Pagellus erythrinus) is distributed throughout the Mediterranean Sea and the northeastern Atlantic Ocean from Norway to Cape Verde (Bauchot and Hureau, 1986; Whitehead et al., 1984-1986). This fish is a protogynous hermaphrodite, and individuals are first female and become male in the third or fourth year of life. The length of time of sex reversal for common pandora is different among the different regions of the Mediterranean Sea (Zei and Županović, 1961; Klaoudatos and Klaoudatos, 2004; Zarrad et al., 2010; Saoudi et al., 2017). This species inhabits shallow waters down to $120 \mathrm{~m}$, mostly among rock, gravel, and sandy-muddy sediments (Jukić and Arneri, 1984; Papaconstantinou et al., 1988). The spawning period of this species has been reported to occur from spring to early autumn depending on region and hydrological conditions (Pajuelo and Lorenzo, 1998; Coelho et al., 2010; Metin et al., 2011).

The common pandora is a highvalue species among the porgies (Sparidae) (Coelho et al., 2010). This species is an important demersal resource throughout the Mediterranean Sea and Black Sea. The common pandora is caught in trawls, trammel nets, gill nets, bottom long lines, and hand lines (Metin et al., 2011). Fishing pressure and increased adult mortality have resulted in earlier maturity at a smaller size (Beverton and Holt, 1956). Size at first maturity of the common pandora has been reported to be 11-16 $\mathrm{cm}$ in total length (TL) in the Aegean Sea (Metin et al., 2011), 14-16 cm TL in the central Mediterranean Sea (Zarrad et al., 2010; Ali Ben Smida et al., 2014), 17-18 cm TL off Portugal (Coelho et al., 2010), and 17-23 $\mathrm{cm}$ TL off the Canary Islands (Pajuelo and Lorenzo, 1998).

Information on population parameters, such as daily age, growth, and hatching times of heavily exploited fish species provide important information for stock assessments and fishery management (Aliaume et al., 2000). The common pandora is listed in the IUCN Red List of Threatened Species as a species of least concern (Russell, 2014). Despite the wide distribution and ecological and economic importance of this species, most studies on the age and growth rates of this species have focused on adult individuals, and there is no study on age and growth of early life stages. However, information on early life stages is essential for understanding population traits, such as recruitment and productivity. 


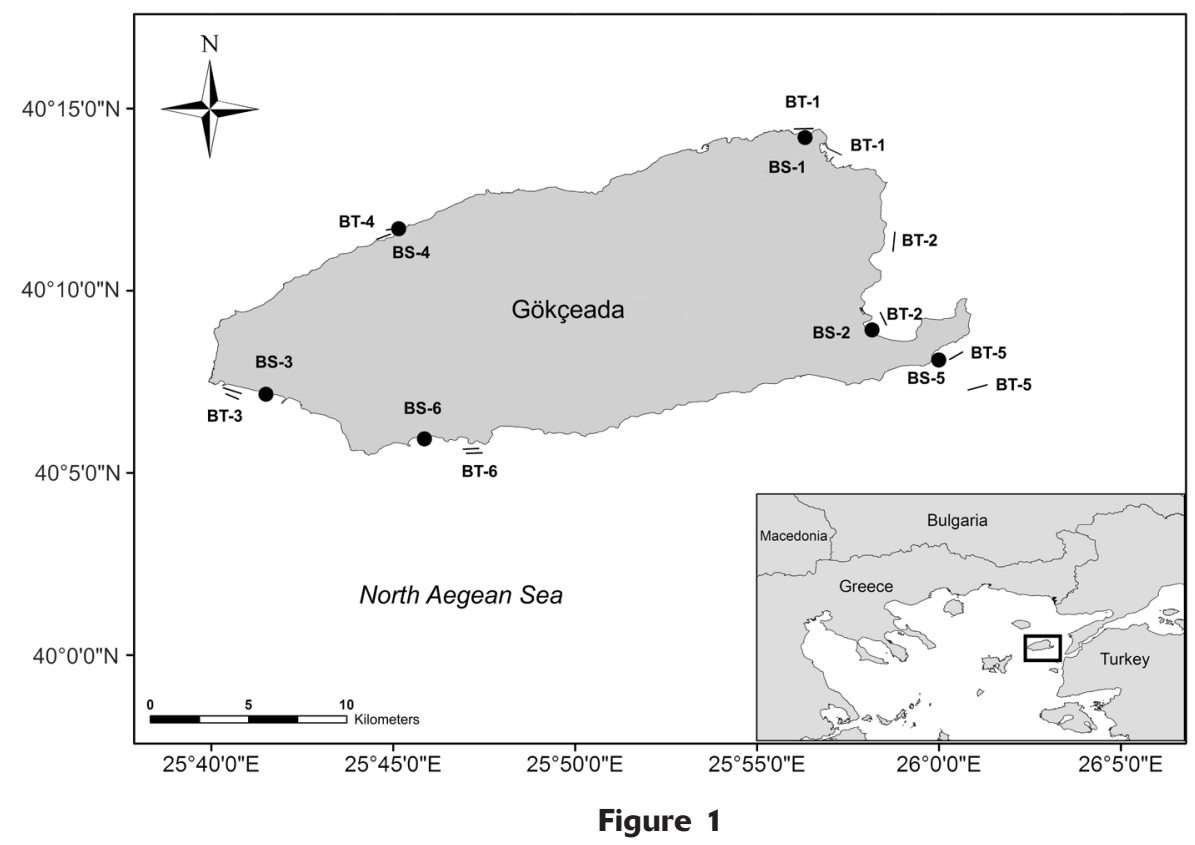

Six sampling stations where young-of-the-year common pandora (Pagellus erythrinus) were collected with beach seine (BS) or beam trawl (BT) from the shallow waters $(<20 \mathrm{~m})$ off the island of Gökçeada, Turkey, from June 2013 through June 2014.

In this study, we investigated young-of-the-year (YOY) age, growth rates, and back-calculated hatching dates of common pandora collected from the island of Gökçeada, Turkey, by analyzing their otolith microstructure. We also examined the relationships between otolith morphometric measurements (length, width, and radius) and fish total length.

\section{Materials and methods}

During the daytime, YOY common pandora were collected with a beach seine and beam trawl from 6 sites in shallow waters $(<20 \mathrm{~m})$ off Gökçeada, Turkey (Fig. 1). Samples were taken from June 2013 through June 2014. Beam trawling speed was $2-3 \mathrm{kt}$. The beach seine hauls were made parallel to the shore.

Total length of common pandora was measured to the nearest $1 \mathrm{~mm}$, and total weight was measured with a digital balance with precision to $0.01 \mathrm{~g}$. A total of 261 pairs of sagittal otoliths were removed, cleaned, and placed in clean, labeled vials. One otolith of the sagittal pair was randomly selected and subsequently embedded in epoxy resin, mounted on a glass slide, and ground to expose the core (Miller and Storck, 1982; Secor et al. ${ }^{1}$; Jones, 1992; Hayes, 1995).

\footnotetext{
${ }^{1}$ Secor, D. H., J. M. Dean, and E. H. Laban. 1991. Manual for otolith removal and preparation for microstructural examination. Belle W. Baruch Inst. Mar. Biol. Coast. Res., Tech. Publ. 1991-01, 55 p. [Available from Belle W. Baruch Inst. Mar. Coast. Sci., Univ. South Carolina, Columbia, SC 29208.]
}

Otolith daily growth rings were counted from the core to the outer edge under a light microscope at magnifications of $40 \times$ and $100 \times$ (Fig. 2). The number of daily increments between right and left otoliths were compared with a paired $t$-test. Two readers independently counted the daily rings without prior knowledge of fish length, and, when counts differed from each other by more than $10 \%$, these otoliths were not included in the study.

Estimates of the precision of daily growth ring counts between readers were determined by using the average percentage error (APE) of Beamish and Fournier (1981) and coefficient of variation (CV) (Chang, 1982).

It was assumed that growth increments in the sagittal otoliths are formed daily. Daily ring formation has not been validated for common pandora; however, it has been validated for many fish species (Pannella, 1971; Campana and Neilson, 1985). The slope of the regression analysis of the TL and the number of otolith daily growth rings was used to estimate the overall YOY growth rates. Daily growth rates for the capture date of each cohort (except when the number of samples $(n)$ was $<5$, see Table 3 ) also were estimated by fitting a linear model. The differences in slopes were compared by using an analysis of covariance (ANCOVA) to identify the significant differences in daily growth for each cohort.

Otolith morphometric measurements (otolith length $[\mathrm{OL}]$, width $[\mathrm{OW}]$, and radius $[\mathrm{OR}]$ ) were measured to the nearest $0.001 \mathrm{~mm}$ by using QCapture Pro ${ }^{2}$ imaging

\footnotetext{
${ }^{2}$ Mention of trade names or commercial companies is for identification purposes only and does not imply endorsement by the National Marine Fisheries Service, NOAA.
} 


\begin{tabular}{|c|c|c|c|c|c|}
\hline \multicolumn{6}{|c|}{$\begin{array}{l}\text { Summary of the total lengths in millimeters of young-of-the-year common Pandora } \\
\text { (Pagellus erythrinus) collected in the shallow waters }(<20 \mathrm{~m}) \text { off Gökçeada, Turkey, } \\
\text { from June } 2013 \text { through June } 2014 \text {. The number of specimens }(n) \text { and range, mean, } \\
\text { and standard error of the mean (SE) for total length are provided. }\end{array}$} \\
\hline Month of capture & $n$ & Min & Max & Mean & $\mathrm{SE}$ \\
\hline March & 3 & 51 & 82 & 65.67 & 8.99 \\
\hline April & 1 & 110 & 110 & 110.00 & $\ldots$ \\
\hline May & 1 & 85 & 85 & 85.00 & $\ldots$ \\
\hline June & 42 & 15 & 73 & 45.33 & 1.97 \\
\hline July & 67 & 12 & 80 & 41.73 & 2.37 \\
\hline August & 34 & 25 & 70 & 47.47 & 2.08 \\
\hline September & 3 & 18 & 33 & 25.33 & 4.33 \\
\hline October & 43 & 13 & 98 & 25.74 & 2.93 \\
\hline November & 66 & 16 & 86 & 32.98 & 1.88 \\
\hline December & 1 & 43 & 43 & 43.00 & $\ldots$ \\
\hline
\end{tabular}

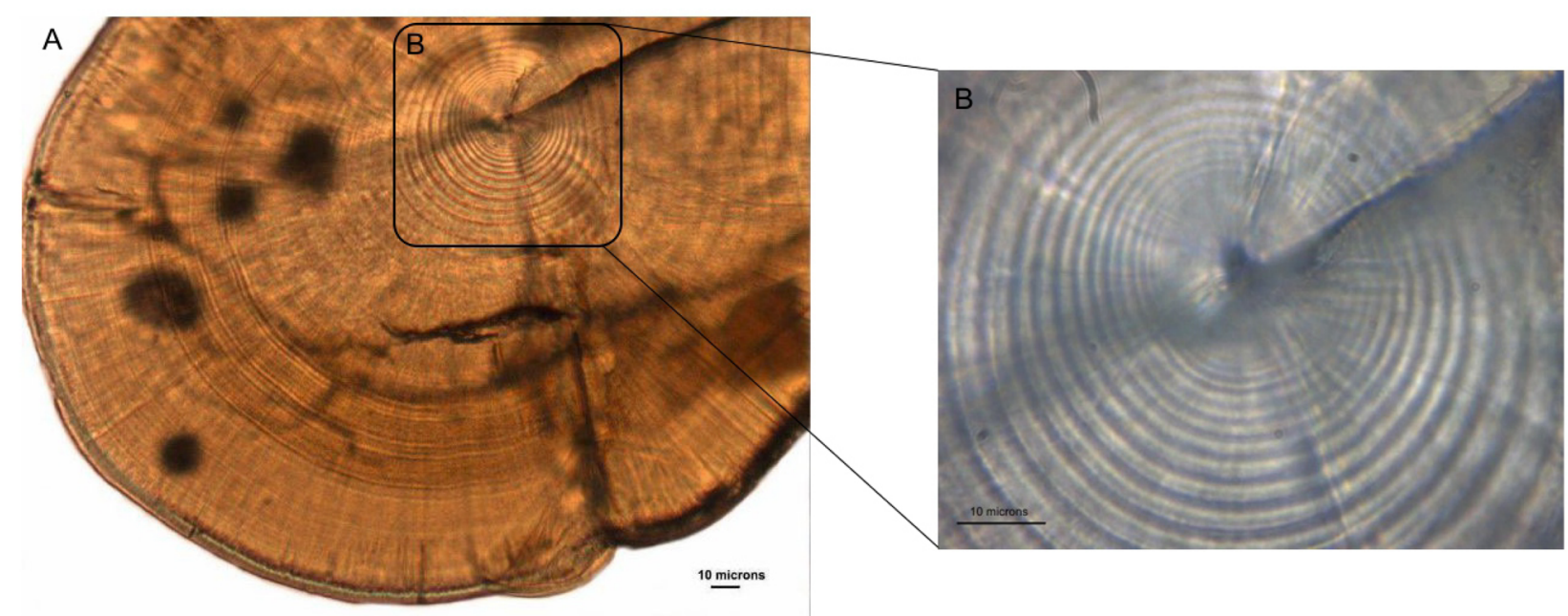

Figure 2

(A) Images of the daily growth rings seen in a polished sagittal otolith of a young-of-the-year common pandora (Pagellus erythrinus) collected in November 2013 off Gökçeada, Turkey. (B) Showing the otolith core. This fish was aged at $59 \mathrm{~d}$ and had a total length of $22 \mathrm{~mm}$.

software (vers. 5.1; QImaging, Surrey, Canada). Otolith length is the longest axis between the anterior and posterior otolith edge, and $\mathrm{OW}$ is the distance from the dorsal to the ventral edge. Otolith radius is the longest axis between the core and posterior edge. A linear regression was used to describe the relationship between fish TL and otolith morphometric measurements for YOY common pandora.

Distributions of hatching dates of YOY common pandora were back-calculated from daily age estimates and date of capture. No mortality correction was applied to the hatching-date distributions (Campana and Jones, 1992).

\section{Results}

A total of 261 YOY common pandora were sampled from shallow waters off the island of Gökçeada. Youngof-the-year fish ranged in size from 12 to $110 \mathrm{~mm}$ TL (Table 1). Thirty pairs of sagittal otoliths were rejected because they were over ground or cracked, or there were discrepancies in daily ring counts among the age readers. Daily ages were determined successfully from 231 otoliths of YOY common pandora that ranged in size from 12 to $110 \mathrm{~mm}$ TL. We found that the average length of specimens increased with bottom depth (Fig. 3). 


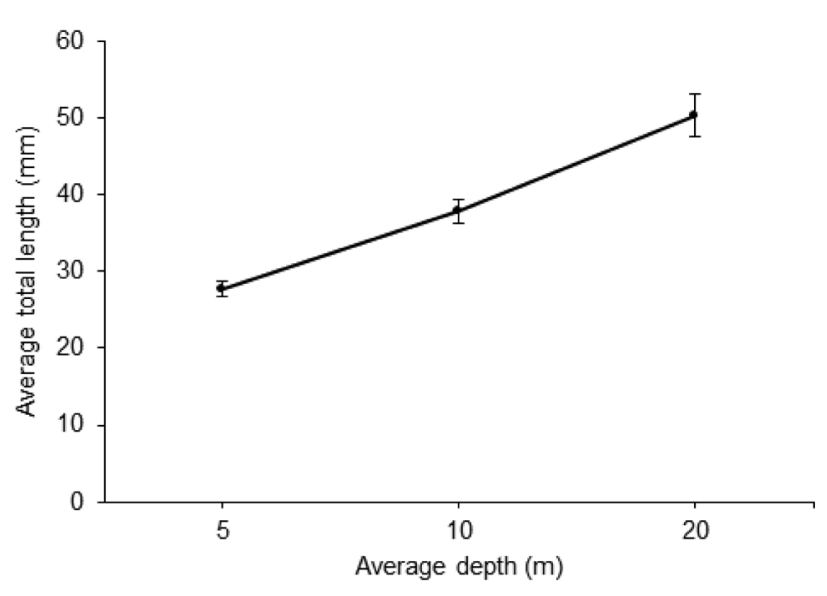

Figure 3

Relationships between average depth and mean total lengths of young-of-the-year common pandora (Pagellus erythrinus) collected off Gökçeada, Turkey, during June 2013-June 2014.

There was no significant difference between the numbers of daily growth increments counted for the left and right otoliths (paired $t$-test: $n=30, P>0.05$ ). Therefore, only one otolith was randomly selected for daily age estimation. The maximum observed age was $242 \mathrm{~d}$ (for a fish at $110 \mathrm{~mm}$ TL), and the minimum observed age was $38 \mathrm{~d}$ (for a fish at $12 \mathrm{~mm}$ TL). The age group 58-77 d (for fish at 18-41 mm TL) was dominant (25.5\%). Specimens of age groups 198-217 and 218-237 were absent. The APE and CV were calculated as $4.9 \%$ and $3.4 \%$, respectively.

Sagittal otolith length, width, and radius were ob-

\section{Table 2}

Parameters of the linear relationship of the different otolith morphometric measurements, otolith length $(\mathrm{OL})$, otolith width $(\mathrm{OW})$, and otolith radius $(\mathrm{OR})$, with fish length for young-of-the-year common pandora (Pagellus erythrinus) collected off Gökçeada, Turkey, during June 2013-June 2014. The number of specimens $(n)$, y-intercept $(a)$, slope of the regression line $(b)$, and coefficient of determination $\left(r^{2}\right)$ are provided.

\begin{tabular}{lccccc}
\hline $\begin{array}{l}\text { Morphometric } \\
\text { measurements }\end{array}$ & $n$ & $a$ & $b$ & $r^{2}$ & $P$ \\
\hline OL & 228 & 2.407 & 21.271 & 0.975 & $<0.01$ \\
OW & 228 & 2.702 & 30.315 & 0.961 & $<0.01$ \\
OR & 198 & 4.249 & 41.875 & 0.942 & $<0.01$
\end{tabular}

served in the ranges of $0.37-7.07 \mathrm{~mm}, 0.26-5.03$ $\mathrm{mm}$, and 0.18-3.59 $\mathrm{mm}$, respectively. Relationships between TL and otolith morphometric measurements (OL, OW, and OR) were described by linear equations (Table 2).

The daily growth rate of YOY common pandora was estimated as $0.52 \mathrm{~mm} / \mathrm{d}$ (Fig. 4). The maximum daily growth rate of $0.54 \mathrm{~mm} / \mathrm{d}$ was found in the June cohort, and the minimum value of $0.46 \mathrm{~mm} / \mathrm{d}$ was observed in the August cohort (Table 3). However, there were no statistically significant differences in either slope or adjusted mean among the equations (ANCOVA: $F=1.216$, df=4, $P=0.305$ ).

Spawning of YOY common pandora took place in 2 peaks represented by overlapping normal distributions (Fig. 5). The first spawning peak was observed in

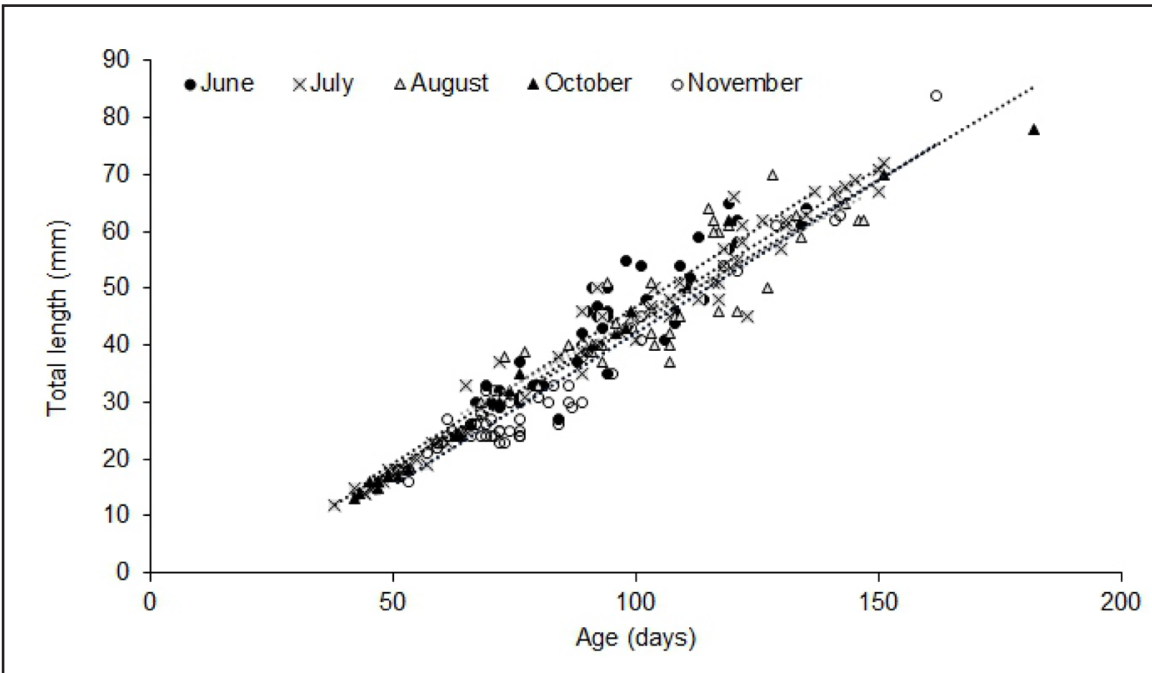

Figure 4

Age-length relationships estimated for young-of-the-year common pandora ( $\mathrm{Pa}$ gellus erythrinus) collected off Gökçeada, Turkey during June 2013-June 2014. 


\section{Table 3}

Parameters of the linear models for the relationship between total length (TL) and number of daily increments (age) for young-of-the-year common pandora (Pagellus erythrinus) collected off Gökçeada, Turkey, during June 2013-June 2014. The number of specimens $(n)$, size and age range with standard error of the mean (SE), y-intercept $(a)$, slope of the regression line $(b)$, and coefficient of determination $\left(r^{2}\right)$ are provided. Capture months during which less than 5 specimens were collected are not included.

\begin{tabular}{|c|c|c|c|c|c|c|c|c|c|}
\hline Month of capture & $n$ & Size (mm TL) & $\mathrm{SE}$ & $\begin{array}{c}\text { Number of } \\
\text { daily increments } \\
\text { (age) }\end{array}$ & $\mathrm{SE}$ & $a$ & $b$ & $r^{2}$ & $P$ \\
\hline June & 42 & $15-73$ & 1.97 & $46-137$ & 3.14 & 8.17 & 0.54 & 0.84 & $<0.01$ \\
\hline July & 67 & $42-63$ & 2.37 & $38-151$ & 4.25 & 8.06 & 0.52 & 0.96 & $<0.01$ \\
\hline August & 34 & $25-70$ & 2.08 & $64-147$ & 3.85 & 1.55 & 0.46 & 0.73 & $<0.01$ \\
\hline October & 43 & $13-98$ & 2.93 & $42-182$ & 5.48 & 7.30 & 0.50 & 0.97 & $<0.01$ \\
\hline November & 66 & $16-86$ & 1.88 & $51-162$ & 2.79 & 11.55 & 0.53 & 0.92 & $<0.01$ \\
\hline All & 231 & $12-110$ & 21.12 & $38-242$ & 31.59 & 8.41 & 0.52 & 0.93 & $<0.01$ \\
\hline
\end{tabular}

spring (March), and the second one was seen in summer (August). The hatching times of common pandora were back-calculated to occur between February and October.

\section{Discussion}

This study provides the first estimates of daily age and growth rates for the YOY of common pandora. Distinct light and dark bands, which can be used for age determination, were observed in the examined otoliths of YOY common pandora. Daily increment formation in otoliths is a general phenomenon that has been vali- dated for many other species (Pannella, 1971; Campana and Neilson, 1985; Jones, 1992). Therefore, formation of increments on the otoliths of common pandora were assumed to occur daily. Campana (2001) suggested that acceptable levels for APE and CV were 5.5\% and 7.6\%, respectively. Therefore, our results $(4.9 \%$ and $3.4 \%$, respectively) are close to the acceptable values for both $\mathrm{APE}$ and $\mathrm{CV}$.

Our findings are consistent with those of Somarakis and Machias (2002), who reported that the mean sizes of common pandora increased with bottom depth because smaller individuals were found in shallower and warmer waters. Few researchers have also addressed whether the decline in the number of older fish may 
not only be due to mortality but also partially to movements of larger fish to deeper waters (Harmelin-Vivien et al., 1995; Ayyildiz et al., 2015).

No previous studies have used otolith microstructure analysis on age and growth rates of the early life stages of the common pandora. Therefore, we compared the data from our study of common pandora at early life stages with lengths at age 0 reported for adult common pandora in previous studies. The results of a recent study by Somarakis and Machias (2002) indicate that common pandora can reach a size of $120 \mathrm{~mm}$ TL at age 0 . Similarly, a specimen of common pandora with a size of $100 \mathrm{~mm}$ TL was found at age 0 by $\mathrm{Pa}-$ juelo and Lorenzo (1998). These results are supported by Hoşsucu and Çakır (2003), who found that average size at age 0 of common pandora was $77-78 \mathrm{~mm}$ TL and average size at 1 year of age was 117-119 $\mathrm{mm}$ TL. The results of our study match those observed in these earlier studies.

It is possible to estimate the length of fish by using morphometric measurements of otoliths (Harvey et al., 2000; Campana, 2004; Zan et al., 2015). Morphometric characteristics of the sagittal otoliths of YOY common pandora were linearly related to the logarithm of fish TL. Our results are consistent with those of other studies and indicate that the relationships between fish TL and otolith morphometric measurements are usually log linear (Ayyildiz et al., 2014; Dehghani et al., 2016; Al-Busaidi et al., 2017). However, according to Lleonart et al. (2000), the linear model is not appropriate because it cannot detect changes in the shape of otoliths.

The hatching times of common pandora were backcalculated to occur between February and October, and 2 main cohorts were estimated to occur in the spring (March) and summer (August). This result broadly agrees with the findings of Hoşsucu and Çakır (2003) and Zarrad et al. (2010) that indicate that the reproductive season of common pandora extended from April to October. Several studies also have revealed that the duration of the reproductive season of common pandora extends from April to September and peak spawning activity occurs between June and August (Pajuelo and Lorenzo, 1998; Valdés et al., 2004). A recent study by Coelho et al. (2010) reported a similar reproductive spawning season from March to July.

\section{Acknowledgments}

This study was funded by The Scientific and Technological Research Council of Turkey (project no.: 112Y062).

\section{Literature cited}

Al-Busaidi, H. K., L. A. Jawad, and A. H. Al-Balushi. 2017. Relationships between fish and otolith size of the blackspot snapper Lutjanus ehrenbergii (Peters, 1869) collected from the coast of Muscat City, Sea of Oman. Int. J. Mar. Sci. 7:386-393. Article
Ali Ben Smida, M., N. Hadhri, A. Bolje, M. El Cafsi, and R. Fehri-Bedoui.

2014. Reproductive cycle and size at first sexual maturity of common pandora Pagellus erythrinus (Sparidae) from the Bay of Monastir (Tunisia, central Mediterranean). Ann. Ser. Hist. Nat. 24:31-40.

Aliaume, C., A. Zerbi A., J.-C. Joyeux, and J. M. Miller.

2000. Growth of juvenile Centropomus undecimalis in a tropical island. Environ. Biol. Fish. 59:299-308. Article

Ayyildiz, H., O. Ozen, and A. Altin.

2014. Growth, mortality and hatch-date distributions of striped sea bream Lithognathus mormyrus inhabiting the Çanakkale Strait, Turkey. J. Mar. Biol. Assoc. U. K. 94:607-613. Article

2015. Daily growth rates and hatch date distributions of common two-banded seabream, Diplodus vulgaris inhabiting the Çanakkale shallow waters of Turkey. J. Mar. Biol. Assoc. U. K. 95:185-191. Article

Bauchot, M.-L., and J.-C. Hureau.

1986. Sparidae. In Fishes of the North-eastern Atlantic and the Mediterranean, vol. 2 (P. J. P. Whitehead, M.L. Bauchot, J.-C. Hureau, J. Nielsen, and E. Tortonese, eds.), p. 883-907. UNESCO, Paris.

Beamish, R. J., and D. A. Fournier.

1981. A method for comparing the precision of a set of age determinations. Can. J. Fish. Aquat. Sci. 38:982-983. Article

Beverton, R. J. H., and S. J. Holt.

1956. A review of methods for estimating mortality rates in exploited fish populations, with special reference to sources of bias in catch sampling. Rapp. p.-v. Reun. (Monaco) 140:67-83.

Campana, S. E.

2001. Accuracy, precision and quality control in age determination, including a review of the use and abuse of age validation methods. J. Fish Biol. 59:197-242. Article

2004. Photographic atlas of fish otoliths of the northwest Atlantic Ocean. Can. Spec. Publ. Fish. Aquat. Sci. 133, $284 \mathrm{p}$

Campana, S. E., and Neilson J. D.

1985. Microstructure of fish otoliths. Can. J. Fish. Aquat. Sci. 42:1014-1032. Article

Campana, S. E., and C. M. Jones.

1992. Analysis of otolith microstructure data. In Otolith microstructure examination and analysis (D. K. Stevenson and S. E. Campana, eds.), p. 73-100. Can. Spec. Publ. Fish. Aquat. Sci. 117.

Chang, W. Y. B.

1982. A statistical method for evaluating the reproducibility of age determination. Can. J. Fish. Aquat. Sci. 39:1208-1210. Article

Coelho, R., L. Bentes, C. Correia, J. M. S. Gonçalves, P. G. Lino, P. Monteiro, J. Ribeiro, and K. Erzini.

2010. Life history of the common pandora, Pagellus erythrinus (Linnaeus, 1758) (Actinopterygii: Sparidae) from southern Portugal. Braz. J. Oceanogr. 58:233-245. Article

Dehghani, M., E. Kamrani, A. Salarpouri, and S. Sharifian. 2016. Otolith dimensions (length, width), otolith weight and fish length of Sardinella sindensis (Day, 1878), as index for environmental studies, Persian Gulf, Iran. Mar. Biodivers. Rec. 9:44. Article

Harmelin-Vivien, M. L., J. G. Harmelin, and V. Leboulleux. 1995. Microhabitat requirements for settlement of juvenile sparid fishes on Mediterranean rocky shores. Hydrobiologia 300:309-320. Article 
Harvey, J. T., T. R. Loughlin, M. A. Perez, and D. S. Oxman. 2000. Relationship between fish size and otolith length for 63 species of fishes from the eastern North Pacific Ocean. NOAA Tech. Rep. NMFS 150, 36 p.

Hayes, J. W.

1995. Importance of stream versus early lake rearing for rainbow trout fry in Lake Alexandrina, South Island, New Zealand, determined from otolith daily growth patterns. N. Z. J. Mar. Freshw. Res. 29:409-420. Article

Ho sucu, B., and D. T. Çakır.

2003. Some parameters about population biology of the common pandora (Pagellus erythrinus L., 1758) (Sparidae) in the Edremit Bay (Turkey). E.U. J. Fish. Aquat. Sci. 20:329-336.

Jones, C. M.

1992. Development and application of the otolith increment technique. In Otolith microstructure examination and analysis (D. K. Stevenson, and S. E. Campana, eds.), p. 1-11. Can. Spec. Publ. Fish. Aquat. Sci. 117.

Jukić, S., and E. Arneri.

1984. Distribution of hake (Merluccius merluccius L.), red mullet (Mullus barbatus L.) and pandora (Pagellus erythrinus L.) in the Adriatic sea. FAO Fish. Rep. 290:85-91.

Klaoudatos, S. D., and D. S. Klaoudatos.

2004. Brood stock formation of the hermaphrodite finfish species Pagellus erythrinus (common Pandora) from fish reared in captivity. Mediterr. Mar. Sci. 5:187-198. Article

Lleonart, J., J. Salat, and G. J. Torres.

2000. Removing allometric effects of body size in morphological analysis. J. Theor. Biol. 205:85-93. Article

Metin, G., A. T. Ilkyaz, O. Soykan, and H. T. Kinacigil.

2011. Biological characteristics of the common pandora, Pagellus erythrinus (Linnaeus, 1758), in the central Aegean Sea. Turkish J. Zool. 35:307-315. Article

Miller, S. J., and T. Storck.

1982. Daily growth rings in otoliths of young-of-the-year largemouth bass. Trans. Am. Fish. Soc. 111:527-530. Article

Pajuelo, J. G., and J. M. Lorenzo.

1998. Population biology of the common pandora $\mathrm{Pa}$ gellus erythrinus (Pisces: Sparidae) off the Canary Islands. Fish. Res. 36:75-86. Article
Pannella, G.

1971. Fish otoliths: daily growth layers and periodical patterns. Science 173:1124-1127. Article

Papaconstantinou, C., C. Mytilineou, and T. Panos.

1988. Aspects of the life history and fishery of red pandora, Pagellus erythrinus (Sparidae) off western Greece. Cybium 12:267-280.

Russell, B.

2014. Pagellus erythrinus. The IUCN Red List of Threatened Species 2014: e.T170224A1296530. [Available from website, accessed May 2017.]

Saoudi, H., A. Saoudi, C. E. Mimar, and L. Aoun.

2017. Analysis of hermaphroditism in Pagellus erythrinus (Linnaeus, 1758) fished in the Gulf of Annaba, Algeria, Mediterranean Sea. AACL Bioflux 10:1330-1341.

Somarakis, S., and A. Machias.

2002. Age, growth and bathymetric distribution of red pandora (Pagellus erythrinus) on the Cretan shelf (eastern Mediterranean). J. Mar. Biol. Assoc. U. K. 82:149-160. Article

Valdés, P., A. García-Alcázar, I. Abdel, M. Arizcun, C. Suárez, and E. Abellán.

2004. Seasonal changes on gonadosomatic index and maturation stages in common pandora Pagellus erythrinus (L.). Aquac. Int. 12:333-343. Article

Whitehead, P. J. P., M.-L. Bauchot, J.-C. Hureau, J. Nielsen, and E. Tortonese.

1984-1986. Fishes of the north-eastern Atlantic and the Mediterranean, 3 vols. UNESCO, Paris.

Zan, X.-X., C. Zhang, B.-D. Xu, and C.-L. Zhang.

2015. Relationships between fish size and otolith measurements for 33 fish species caught by bottom trawl in Haizhou Bay, China. J. Appl. Ichthyol. 31:544-548. Article

Zarrad, R., M. Cherif, H. Gharbi, O. Jarboui, and H. Missaoui. 2010. Reproductive cycle and sex reversal of Pagellus erythrinus (Linnaeus, 1758) in the Gulf of Tunis (central Mediterranean). Bull. Inst. Natl. Sci. Tech. Mer Salammbô 37:13-20.

Zei, M., and S. Županović.

1961. Contribution to the sexual cycle and sex reversal in Pagellus erythrinus, L. Rapp. p.-v. Rèun (Monaco) 16:263-267. 